\title{
Evaluating Public Transportation Local Funding Options
}

\author{
Todd Litman, Victoria Transport Policy Institute
}

\begin{abstract}
This report describes and evaluates 18 potential local funding options suitable for financing public transportation projects and services. They are evaluated according to eight criteria, including potential revenue, predictability and sustainability, horizontal and vertical equity, travel impacts, strategic development objectives, public acceptance and ease of implementation. This is a somewhat larger set of options and more detailed and systematic evaluation than most previous studies. This study discovered no new options that are particularly cost-effective and easy to implement; each has disadvantages and constraints. As a result, its overall conclusion is that a variety of funding options should be used to help finance the local share of public transit improvements to ensure stability and distribute costs broadly.
\end{abstract}

\section{Introduction}

High-quality public transit can provide various economic, social, and environmental benefits, including direct user benefits and various indirect and external benefits. Residents of communities with high-quality transit tend to own fewer motor vehicles, drive less, and spend less on transport than they would in more automobileoriented locations. Governments and businesses can save roadway and parking facility costs. It can support economic development. Appropriate public transit investments can provide positive economic returns: under favorable conditions transit investments provide savings and benefits that more than offset costs (Litman 2010). As a result, public transit service improvements are an important component of many jurisdictions' strategic transport plans (Buehler and Pucher 2010). 
Although federal and state/provincial funds often help finance transit improvements, additional local funding is generally needed. Several previous studies identify and evaluate potential public transit funding sources, but most consider only a relatively limited set of options and evaluation criteria. This report evaluates 18 potential local funding options according to 8 criteria, including potential revenue, predictability and sustainability, horizontal and vertical equity, travel impacts, strategic development objectives, public acceptance and ease of implementation. This is a somewhat larger set of options and evaluation criteria than considered in most previous studies. Much of this analysis can be applied to any type of transportation improvement, not just public transit.

\section{Literature Review}

This section summarizes several recent studies of potential transportation and public transit funding options.

"Primer on Transit Funding: FY 2004 through FY 2012" (APTA 2012) describes existing U.S. public transit funding, including federal and state grant programs and various regional and local funding sources, including general fund, gas tax motor vehicle, rental car sales tax, vehicle registration fees, bond proceeds, general sales tax, and interest income.

"Local and Regional Funding Mechanisms for Public Transportation" and its online "Regional Funding Database" (TCRP 2009) provides an extensive list of local and regional funding sources that are or could be used to support public transit, plus guidance on factors to consider when evaluating and implementing these options. Table 1 summarizes the funding options identified. It evaluates them based on revenue yield (adequacy and stability), cost efficiency, equity across demographic and income groups, degree to which beneficiaries pay, political and popular acceptability, and technical feasibility.

The "Guide to Transportation Funding Options" (UTCM 2010) by the Texas Transportation Institute's University Transportation Center for Mobility provides information on various transit funding options. 


\section{Table 1. U.S. Local and Regional Public Transport Funding Options}

\begin{tabular}{|c|c|c|c|}
\hline $\begin{array}{l}\text { Traditional Tax- and } \\
\text { Fee-Based Transit } \\
\text { Funding Sources }\end{array}$ & $\begin{array}{l}\text { Common Business, } \\
\text { Activity, and Related } \\
\text { Funding Sources }\end{array}$ & $\begin{array}{c}\text { Revenue Streams from } \\
\text { Projects (Transportation } \\
\text { and Others) }\end{array}$ & $\begin{array}{l}\text { New “User” or } \\
\text { “Market-Based” } \\
\text { Funding Sources }\end{array}$ \\
\hline $\begin{array}{l}\text { - General revenues } \\
\text { - Sales taxes } \\
\text { - Property taxes } \\
\text { - Contract or } \\
\text { purchase-of-service } \\
\text { revenues (school/ } \\
\text { universities, private } \\
\text { organizations, etc.) } \\
\text { - Lease revenues } \\
\text { - Vehicle fees (title, } \\
\text { registration, tags, } \\
\text { inspection) } \\
\text { - Advertising } \\
\text { revenues } \\
\text { - Concessions } \\
\text { revenues }\end{array}$ & $\begin{array}{l}\text { - Employer/payroll } \\
\text { taxes } \\
\text { - Vehicle rental and } \\
\text { lease fees } \\
\text { - Parking fees } \\
\text { - Realty transfer tax } \\
\text { - Corporate franchise } \\
\text { taxes } \\
\text { - Room/occupancy } \\
\text { taxes } \\
\text { - Business license fees } \\
\text { - Utility fees/taxes } \\
\text { - Income taxes } \\
\text { - Donations } \\
\text { - Other business } \\
\text { taxes }\end{array}$ & $\begin{array}{l}\text { - Transit-oriented } \\
\text { development (TOD)/ } \\
\text { joint development } \\
\text { - Value capture/ } \\
\text { beneficiary charges } \\
\text { - Special assessment } \\
\text { districts } \\
\text { - Community } \\
\text { improvement districts/ } \\
\text { community facilities } \\
\text { districts } \\
\text { - Impact fees } \\
\text { - Tax-increment financing } \\
\text { districts } \\
\text { - Right-of-way leasing }\end{array}$ & $\begin{array}{l}\text { - Tolling (fixed, } \\
\text { variable, } \\
\text { dynamic; } \\
\text { bridge/roadway) } \\
\text { - Congestion } \\
\text { pricing } \\
\text { - Emissions fees } \\
\text { - VMT fees }\end{array}$ \\
\hline
\end{tabular}

Source: TCRP 2009

"Finding Solutions to Fund Transit: Combining Accountability and New Resources for World-Class Public Transportation" (IPIRG 2007) identifies and evaluates various public transit funding options and evaluated them according to seven principles: market efficiency, low collection costs, reliability, diversity, "fare increases are self-defeating," budget accountability and community participation. It evaluated general sales taxes, dedicated gasoline taxes, car rental taxes, registration fees, tire taxes, weight-based vehicle registration fees, vehicle battery taxes, weigh-mile truck fees, road tolls, development impact fees, stormwater fees, real estate transfer taxes and parking taxes.

"Financing Sustainable Urban Transport" (Sakamoto Belka and Metschies 2010) provides information on available options for financing urban transport improvements, particularly in developing countries. It identifies various funding options and evaluates them based on administrative levels, potential revenues, efficiency, equity, environmental objectives, stability, political acceptability and administrative ease. It provides numerous examples and case studies from around the world.

"The Move Ahead: Funding 'The Big Move'" (TBoT 2010) describes and evaluates potential options for funding The Big Move, a 25-year, $\$ 50$ billion regional transport infrastructure program. Each option is evaluated based on technical feasibil- 
ity, projected revenue, predictability, sustainability and durability of the revenue, administrative cost and complexity, impact on travel behavior, and social equity and fairness.

"Financing Transit Systems through Value Capture: An Annotated Bibliography" (Smith and Gihring 2003) summarizes numerous studies concerning the impacts transit service has on nearby property values, and the feasibility of capturing a portion of the incremental value to finance transit improvements.

\section{Evaluation Criteria}

This section describes the eight criteria used to evaluate funding options.

\section{Potential Revenue}

This refers to the amount of money that an option can be expected to generate, based on various assumption about how it is implemented. Some funding options have natural constraints; for example, there are limits to the amount of money transit agencies can generate through advertising and station rents, but, in most cases, maximum potential revenues reflect assumptions about how an option is implemented and what is politically acceptable.

\section{Predictability and Stability}

Funding predictability and stability are desirable for planning and budgeting purposes. Some funding options fluctuate from year to year, while others are more predictable and stable. These evaluations are based on a general understanding of funding options, which may be modified in a particular situation.

\section{Equity Analysis}

One of the most common issues raised in public consultations is a desire that transport funding be equitable - that is, the distribution of costs and benefits should be considered fair and appropriate. Transport equity can be defined and measured in various ways that may lead to different conclusions concerning what is equitable (Litman 2002). There are two major categories:

- Horizontal equity refers to the distribution of impacts between people with similar wealth, needs and abilities. It assumes that similar people should generally be treated equally and implies that people should "get what they pay for and pay for what they get" unless subsidies are specifically justified.

- Vertical equity refers to the distribution of impacts between people who differ in wealth, ability, or need. It generally assumes that costs should be smaller 
and benefits greater for people who are physically, economically or socially disadvantaged. Policies that do this are called progressive, and those that impose higher costs on disadvantaged people are called regressive.

Equity analysis can consider various types of impacts and group people in various ways. For example, road pricing is generally considered regressive, since a given toll represents a larger portion of income to lower-income than to higher-income motorists. However, lower-income people tend to own fewer cars and drive less than wealthier people, particularly on major urban highways that are candidates for tolling. Lower-income people tend to rely more on alternative modes and can benefit directly if congestion pricing reduces delay for rideshare vehicles and buses. As a result, road pricing may be less regressive than other roadway funding options (such as general taxes) and may be progressive overall if it leads to improvements to alternative modes, such as increased investment in cycling facilities and transit services.

Horizontal equity requires that program costs be borne by beneficiaries. Public transit service improvements can provide various benefits to users (internal benefits) and society (external benefits). Some benefits result from the service improvements themselves; others result only if the improves reduce automobile travel or stimulate more compact development (Banister and Thurstain-Goodwin 2011; CTOD 2011; Litman 2011). These include benefits to:

- Transit users, from improved convenience and comfort, financial savings, increased safety, and improved public fitness and health

- Motorists, from reduced traffic and parking congestion, improved mobility for non-drivers (which reduces chauffeuring burdens), improved traffic safety, and emission reductions

- Taxpayers, from road and parking facility cost savings, improved safety, and increased public health

- Businesses, from congestion reductions, parking cost savings, improved employee safety and fitness, and, in various ways, high-quality public transport tends to support regional economic development

- Residents (regardless of how they travel), including parking cost savings, improved mobility for non-drivers, increased safety, reduced pollution, and improved public fitness. 


\section{Travel Impacts}

This refers to the effects an option has on how and how much people travel and the degree that this supports or contradicts strategic transport planning objectives, such as reducing automobile travel and increased use of alternative modes. These are estimated based on our understanding of price impacts on travel activity (Litman 2004, 2013).

\section{Strategic Development Objectives}

This refers to the effects an option has on the type and location of development in a community and whether this supports or contradicts strategic planning objectives, such as objectives to encourage more compact, accessible development and discourage sprawl. These are estimated based on our understanding of tax and price impacts on development patterns.

\section{Public Acceptability}

Public preference and the acceptability of specific funding options can be determined though surveys and public consultations. Such preferences can vary depending on the group surveyed, how questions are phrased, and how funding options are structured and implemented. For example, the public acceptability of a fuel tax increase may depend on existing fuel tax levels, when they were last raised, and how revenues are used.

These impacts can vary significantly, depending on specific conditions and assumptions. Equity impacts are particularly subjective, depending on how equity is defined and impacts measured. As a result, analysis assumptions should be clearly described and, if possible, the public consulted to ensure that all perspectives are represented. For example, it may be useful to use public surveys and focus groups to explore the perceived fairness and acceptability of various potential funding options in a community (Earthvoice Strategies 2012; Quay Communications Inc. 2012).

\section{Ease of Implementation}

This refers to a revenue option's transition (initial implementation) and transaction (ongoing collection) costs. These are estimated based on assumptions about how it will be implemented and what is required to do this. 


\section{Analysis}

This section describes and evaluates 18 potential public transit funding options.

\section{Fare Increases}

In most urban transit systems, current adult fares average $\$ 2-\$ 3$ per trip or $\$ 50-$ $\$ 80$ for a monthly pass, with discounted (concession) fares for youths, older adults, and people with disabilities. It is possible to increase all fares, selected categories, or change price structures, for example, to include higher fares for longer-distance trips or for special services such as light rail or express commuter buses.

- Potential Revenue - The price elasticity of transit ridership with respect to fares is usually -0.2 to -0.5 in the short run (first year), and increases to -0.6 to -0.9 over the long run (5-10 years) (Litman 2004; McCollom and Pratt 2004; Wardman and Shires 2011). This suggests that a 10 percent fare increase typically increases revenue 5-8 percent over the short run and 1-4 percent over the long-run. As a result, rising fare increases revenue, but less than proportionately (raising fares $10 \%$ provides less than $10 \%$ increased revenue), and revenue gains tend to decline over time. These impacts tend to vary depending on the types of riders and types of services. Transit-dependent users and peak-period travelers tend to be less price-sensitive than discretionary travelers (people who could travel by automobile) and off-peak travel.

- Predictability and Stability - As previously described, the additional revenues from fare increases can be difficult to predict with precision and tend to decline over time.

- Horizontal Equity - Since transit services are subsidized, fare increases can be considered horizontally equitable (users pay for the services they receive). However, automobile travel imposes significant external costs, particularly under urban-peak travel conditions, including road and parking subsidies, traffic congestion, accident risks, and pollution damages imposed on others (Litman 2009). Under urban-peak travel conditions, transit subsidies are often smaller than the subsidies that would be required to accommodate additional automobile travel on the same corridor. Described differently, to the degree that shifting travel from automobile to public transport is considered a sacrifice that benefits other people, fare increases can be considered horizontally inequitable because they double-charge transit users.

- Vertical Equity - Since public transit provides basic mobility and many users are lower-income, fare increases tend to be regressive and vertically inequitable. 
This regressivity varies depending on specific factors, such as transit user incomes and price structures.

- Travel Impacts - Fare increases tend to reduce public transit travel and shift travel to automobile. They, therefore, tend to contradict planning objectives to reduce automobile travel.

- Strategic Development Objectives - Transit fare increases may reduce the relative attractiveness of transit-oriented locations, such as downtowns and transit station areas.

- Public Acceptance - Although there is general support for the user pay principle, surveys and focus groups indicate opposition to large fare increases, to keep public transit affordable to lower-income users and encourage transit use.

- Ease of Implementation - Fare increases are easy to implement.

- Legal Status - Most public transit agencies or local governments have the legal ability to increase fares.

- Examples - Most transit agencies regularly increase fares.

\section{Discounted Bulk Transit Passes}

Public transit agencies can sell transit passes to a group, such as all students at a college or university (called a "U-Pass program"), all employees at a worksite, or all residents of a neighborhood. They are often designed to be revenue neutral; the additional transit service costs are at least offset by the additional revenues. For example, if standard monthly passes are priced at $\$ 80$ and used for 40 average monthly trips, the transit agency can sell $\$ 40$ discounted passes to a group of students that average 20 monthly trips or $\$ 20$ to a group of residents that average 10 monthly trips.

- Potential Revenue - Potential revenues depend on the scope of these programs, which could add hundreds, thousands, or tens of thousands of new users. However, this also tends to increase transit service costs.

- Predictability and Stability - Contracts for such services tend to be for one or more years, so transit agencies can generally plan for the additional revenue and ridership on an annual basis. 
- Horizontal Equity - Such passes tend to create cross-subsidies from those participants who seldom or never ride transit to those who ride more than average, although they may benefit from reduced congestion and accident risk.

- Vertical Equity - Since physically- and economically-disadvantaged people tend to ride transit more than average and benefit most from financial savings, and since such programs tend to increase total transit service (for example, allowing increased frequency), this strategy tends to support vertical equity objectives.

- Travel Impacts - This tends to increase transit ridership and reduced automobile travel, although impacts will vary depending on specific circumstances.

- Strategic Development Objectives - This can increase the attractiveness of transit-oriented locations.

- Public Acceptance - There is often high public acceptance of such programs, since they make transit more affordable and encourage transit ridership. U-Pass programs often receive high levels of student support, but neighborhood programs tend to receive less.

- Ease of Implementation - Once a price structure is established implementation is relatively easy.

- Legal Status - Most transit agencies have the legal ability to negotiate discounted fares for particular groups.

- Examples - Many colleges and universities have U-Pass programs that provide transit passes to all students and sometimes staff at a campus (Brown, Hess and Shoup 2003). Boulder, Colorado, offers such a pass to residential neighborhoods, called the Neighborhood Eco Pass (Boulder 2013).

\section{Property Taxes}

Most municipal governments collect property taxes. In many jurisdictions a portion of property taxes are dedicated to public transit.

- Potential Revenue - It is possible to increase property taxes by virtually any amount, but large tax increases are politically difficult and there are many demands on these tax revenues.

- Predictability and Stability - Property taxes are relatively stable. 
- Horizontal Equity - To the degree that public transit improvements increase nearby property values or provide other savings and benefits to nearby residents and businesses (congestion reductions, parking cost savings, household savings, emission reductions, etc.), property tax funding can be considered horizontally equitable.

- Vertical Equity - Property ownership tends to increase with income, and lower-income residents tend to qualify for various property tax discounts and exemptions, so this tax tends to be relatively progressive with respect to income. However, even poor people bear a portion of these taxes through rents, and property taxes are burdensome to some lower-income home owners.

- Travel Impacts - Property taxes have few direct travel impacts.

- Strategic Development Objectives - Large property tax differences may cause development to shift between jurisdictions, but transit taxes are relatively small and usually applied region-wide so impacts are likely to be minimal.

- Public Acceptance - Although property taxes are widely used to finance public transit and tend to be considered a default funding source (the source used if other options are not feasible), there may be resistance to significant increases in this tax.

- Ease of Implementation - Since transit property taxes are already collected in most jurisdictions they would be relatively easy to increase.

- Legal Status - In some jurisdictions, state/provincial legislation or voter approval is required to raise property tax rates.

- Examples (TCRP 2009; UTCM 2010) - Many transit agencies rely on property taxes.

\section{Regional Sales Taxes}

Many jurisdictions (particularly in the U.S.) rely significantly on sales taxes to finance public transit. Variations include special taxes on particular transactions such as hotel room and vehicle rentals.

- Potential Revenue - A regional general sales tax could generate virtually any amount of revenue. Revenues from taxes on sales of particular products tend to be modest. 
- Predictability and Stability - Moderately stable. Sales taxes tend to fluctuate more than property taxes.

- Horizontal Equity - To the degree that public transit benefits consumers, sales taxes can be considered horizontally equitable, although the relationship is indirect (people and businesses that benefit most do not necessarily pay more sales taxes).

- Vertical Equity - Sales taxes are regressive and, therefore, tend to be vertically inequitable.

- Travel Impacts - Sales taxes do not directly affect travel activity.

- Strategic Development Objectives - Large sales tax differences may cause development to shift between jurisdictions, but transit taxes are relatively small and usually applied region-wide so impacts are likely to be minimal.

- Public Acceptance - Mixed. Although there tends to be opposition to most tax increases, sales taxes are among the most often applied to fund transportation programs, including public transit improvements, indicating a moderate degree of public acceptance.

- Ease of Implementation - In jurisdictions that already apply sales taxes, there is minimal cost to increasing such taxes to fund public transit. Where no sales taxes are currently applied, implementation costs would be moderate.

- Legal Status - In many jurisdictions, state/provincial legislation or voter approval is required to raise sales tax rates.

- Examples - Sales taxes are the most common dedicated source of transit funding in the U.S. (IPIRG 2007). According to the Federal Transit Administration's National Transit Database, after federal funds, sales taxes comprised the largest source of revenues for capital spending (38\%) and the second largest source of operating expenses (27\%) after fares (32\%). In 2008, more than two-thirds of Los Angeles County voters approved Measure R, a referendum that established a special 0.5 percent sales tax dedicated to rapid transit and some road infrastructure (METRO 2011).

\section{Fuel Taxes}

Special fuel tax can be collected in a jurisdiction to fund public transit. In some cases a portion of existing fuel tax revenue is dedicated to public transit programs without increasing fuel tax rates. 
- Potential Revenue - Assuming residents average 500 gallons of annual fuel consumption, each cent per gallon of taxes generates $\$ 5$. Although fuel price increases reduce demand (a 10\% price increase typically reduces fuel consumption 2-4\% in the medium-run), a few cents per gallon to fund transit generally have minimal impact (Litman 2013; Wardman and Shires 2011).

- Predictability and Stability - Fuel tax revenue is moderately stable. It tends to fluctuate more than property taxes.

- Horizontal Equity - To the degree that motorists benefit from public transit improvements due to reduced traffic and parking congestion and reduced need to chauffeur non-drivers, and to the degree that automobile travel imposes external costs on non-drivers, fuel taxes can be considered to increase horizontal equity.

- Vertical Equity - Fuel taxes are regressive, but this regressivity is reduced if public transit improvements provide a more convenient and affordable alternative to driving. Described differently, of all possible fuel tax uses, transit improvements are relatively progressive if they improve affordable mobility options.

- Travel Impacts - Fuel tax increases tend to reduce automobile travel and encourage use of alternative modes, although typical transit funding taxes are small and so would have minimal impact. Travel impacts depend on whether the transit tax is in addition to, or a portion of, existing fuel taxes.

- Strategic Development Objectives - Fuel tax increases tend to encourage more compact, multimodal land development, although the effects of this are likely to be minimal.

- Public Acceptance - In general, fuel tax increases tend to be unpopular. However, surveys and focus groups indicate moderate support to fuel tax increases that are dedicated to transportation improvements.

- Ease of Implementation - Implementation is relatively easy and in jurisdictions where fuel taxes are already collected.

- Legal Status - Fuel tax increases often require state or provincial approval.

- Examples - At least 12 U.S. states have local option transit gasoline taxes (TCRP 2009). Such taxes are also common in Canada (TBoT 2010). 


\section{Vehicle Levy}

A vehicle levy is an additional fee for registering vehicles in the region.

- Potential Revenue - Although vehicle levies can be any size, most are $\$ 20-\$ 60$ annually per vehicle, only a portion of which is dedicated to public transit, so their total transit revenue is small to moderate. High levies can motivate some motorists to register their vehicles in other jurisdictions.

- Predictability and Stability - Stable.

- Horizontal Equity - As previously discussed, to the degree that motorists benefit from public transit improvements due to reduced traffic and parking congestion and reduced need to chauffeur non-drivers, and to the degree that automobile travel imposes external costs on non-drivers, a vehicle levy can be considered to increase horizontal equity. However, since vehicle fees do not reflect use (fees are the same for vehicles driven high and low annual mileage), this fee poorly reflects the external costs imposed by a particular vehicle.

- Vertical Equity - This fee tends to be regressive, particularly because lowerincome motorists tend to drive their vehicles lower annual mileage and so pay more per kilometer than higher income motorists on average.

- Travel Impacts - Higher vehicle fees may marginally reduce vehicle ownership and use, but impacts are likely to be small.

- Strategic Development Objectives - No significant impacts.

- Public Acceptance - According to survey and focus group responses, vehicle levies have less public acceptance than other transportation-related revenue options.

- Ease of Implementation - Where vehicle registration fees are already collected an additional levy to fund transportation or public transit programs is easy to apply. Implementation costs are much higher if a special fee collection system must be established.

- Legal Status - In most jurisdictions, this would require state/provincial legislation and support.

- Examples - In the United States, 33 states and 27 local jurisdictions have vehicle registration fees that help finance transportation improvements, which often includes public transport (IPIRG 2007). Vehicle registration fees help finance public transport in many Canadian jurisdictions (TBoT 2010). 


\section{Utility Levy}

This is a special transit levy applied to all utility accounts in the region.

- Potential Revenue - Small. Although such a levy could be any size, they are usually $\$ 10-\$ 40$ annual per meter, or $\$ 5-\$ 20$ per capita.

- Predictability and Stability - Stable.

- Horizontal Equity - Similar to a property tax, a utility levy charges residents.

- Vertical Equity - A utility levy is likely to be relatively regressive, since it is a flat fee per household.

- Travel Impacts - No significant impacts.

- Strategic Development Objectives - No significant impacts.

- Public Acceptance - According to survey and focus group responses, utility levies have low public acceptance. It had the greatest level of opposition of all options presented.

- Ease of Implementation - Relatively easy to implement.

- Legal Status - Would generally require state/provincial legislation.

- Examples (TCRP 2009) - Some jurisdictions have local government utility taxes. TransLink receives a hydro levy of $\$ 1.90$ per month from each electric utility account within its service region, which generates approximately $\$ 18$ million annually (TBoT 2010).

\section{Employee Levy}

This is a levy paid by employers (often only larger employers) located in a transit service area.

- Potential Revenue - Small to moderate potential revenues, depending on the number of employees covered and the level of the levy.

- Predictability and Stability - Stable.

- Horizontal Equity - Can be considered fair to the degree that commuters create traffic congestion and create demand for public transit.

- Vertical Equity - The ultimate incidence of this fee is difficult to predict. It may substitute for wages, reduce total employment, or shift employment location if a large levy is applied just in the urban core. 
- Travel Impacts - Travel impacts are likely to be small.

- Strategic Development Objectives - If applied only in an urban core, it may discourage downtown employment and encourage sprawl.

- Public Acceptance - Uncertain.

- Ease of Implementation - Would probably involve moderate implementation costs, similar to other business taxes and fees.

- Legal Status - May require state/provincial legislation.

- Examples (TBoT 2010; TCRP 2009) - In France, the Versement Transport (Transport Levy) taxes employers with more than nine staff to help finance local public transport services. A special 0.6 percent payroll tax is collected from most employers in the Portland and Eugene, Oregon, regions to help finance public transport services.

\section{Road Tolls}

Tolls are user fees for driving on a particular road or bridge or in a particular area. A variation is High Occupancy Tolls (HOT) lanes, which are free for use by high occupant vehicles (buses and carpools) but require a fee for use by single-occupant vehicles. Congestion pricing refers to tolls that are higher during peak periods to reduce traffic congestion.

- Potential Revenue - Although revenues are theoretically large if widely applied, most proposals only toll a minor portion of roads and vehicle travel, resulting in modest total revenues. For example, if 20 percent of commuters pay $\$ 1.00$ per trip ( $\$ 2.00$ for a round-trip commute), revenues would average about $\$ 50$ per capita.

- Predictability and Stability - Once established, revenues would probably be moderately stable, but may decline over the long run as travelers take tolls into account when making longer-term decisions (such as where to live).

- Horizontal Equity - Tolls are generally considered vertically equitable, because they charge users directly for the congestion and roadway costs they impose, but they are often criticized as unfair if they only apply to a few roadways.

- Vertical Equity - Tolls are often criticized as regressive, since a given toll represents a higher portion of income for poorer than wealthier motorists, but overall regressivity depends on the incomes of actual road users, the quality 
of travel options on that corridor and how revenues are used. Tolls are often progressive compared with other funding options, such as using general taxes to finance roads and public transit services.

- Travel Impacts - Road tolls tend to reduce affected automobile travel and traffic congestion, particularly if implemented with public transit improvements.

- Strategic Development Objectives - Mixed. If applied only in central areas, tolls may encourage more dispersed development, but if applied broadly and implemented with improvements to other modes, they may encourage compact development.

- Public Acceptance - There is often public opposition to tolls, particularly on existing roadways, although surveys indicate some acceptance if revenues are used to support popular road and public transport improvements.

- Ease of Implementation - Although there are many possible ways to implement road tolls, including new technologies that reduce costs; implementation is likely to be expensive, particularly if implemented by a single region.

- Legal Status - Road tolling usually requires state/provincial legislation.

- Examples (TBoT 2010; TCRP 2009) - London, Singapore, and Stockholm apply congestion tolls for driving on urban roads during peak periods. New York City uses bridge toll revenue to finance both highways and public transit services

\section{Vehicle-Km Tax}

This is a form of road pricing that charges motorists per kilometer traveled. It could vary by vehicle type, such as higher fees for higher polluting vehicles.

- Potential Revenue - Potentially large.

- Predictability and Stability - Moderate. Similar to fuel taxes.

- Horizontal Equity - Similar to fuel taxes. To the degree that motorists benefit from public transit improvements, and to the degree that automobile travel imposes external costs on non-drivers, vehicle-kilometer fees can be considered to increase horizontal equity.

- Vertical Equity - Likely to be regressive. However, to the degree that public transit improvements reduce the need to drive, this regressivity is reduced. 
- Travel Impacts - Vehicle-kilometer fees tend to reduce automobile travel and encourage use of alternative modes, including public transit.

- Strategic Development Objectives - Vehicle-kilometer fees tend to encourage more compact, multi-modal land development.

- Public Acceptance - In general, vehicle-kilometer fees tend to be unpopular.

- Ease of Implementation - Would have high implementation costs since it would require a special system to measure annual vehicle travel in a region.

- Legal Status - Would generally require federal state or provincial legislation and support.

- Examples (Huang, et al, 2010; TBoT 2010) - Vehicle-kilometer fees have been proposed in many jurisdictions, but so far have only been implemented for freight trucks. For example, in Germany freight trucks are charged a fee of $€ 0.09$ to $€ 0.14$ per kilometer based on their emissions levels and number of axles

\section{Parking Sales Taxes}

This is a special tax on parking transactions (when motorists pay directly for parking).

- Potential Revenue - Small to moderate. Only a minor portion (probably $5-10 \%)$ of parking activity is priced. It could encourage more businesses to provide free parking to employees and customers.

- Predictability and Stability - Moderate to low stability.

- Horizontal Equity - As with other vehicle use fees, it can be considered horizontally equitable to the degree that transit improvements benefit motorists and to the degree that motor vehicle travel imposes external costs.

- Vertical Equity - Since this fee applies only when parking is priced, it is probably less regressive than other vehicle fees.

- Travel Impacts - By marginally increasing parking fees it may slightly reduce vehicle trips, but by increasing the value to users of parking subsidies and reducing commercial parking profitability, it may reduce the total portion of parking that is priced (Litman 2013; Wardman and Shire 2011).

- Strategic Development Objectives - Because this fee primarily applies in downtowns and other major commercial centers, it may discourage compact development. 
- Public Acceptance - There is often public opposition to parking fees. Survey and focus group responses indicate moderate support for this option.

- Ease of Implementation - Implementation costs are likely to be small to moderate. It may require new accounting requirements for commercial parking operators.

- Legal Status - Requires provincial or state legislation and support.

- Examples (Litman 2012; TBoT 2010) - Many U.S. jurisdictions levy a parking surcharge. Chicago assesses a flat parking surcharge rather than a percentage charge on daily, weekly, and monthly parking, with charges ranging from $\$ 0.75-\$ 2$ for daily parking, $\$ 3.75-\$ 10$ for weekly and $\$ 15-\$ 40$ for monthly parking.

\section{Parking Levy}

This is a special property tax on non-residential parking spaces throughout the region.

- Potential Revenue - Potential revenue is large. Assuming that there are one to two qualifying parking spaces per capita, a $\$ 50$ per space annual tax could generate $\$ 100$ annually per capita.

- Predictability and Stability - Relatively stable, although revenues could decline slightly over time if property owners are allowed to reduce their parking supply.

- Horizontal Equity - Like a fuel tax, this can be considered fair to the degree that motorists benefit from public transit improvements or to the degree that parking facilities or automobile travel impose currently uncompensated external costs.

- Vertical Equity - The ultimate incidence of this tax is difficult to predict and will vary depending on specific conditions. It will mainly be borne by commercial property owners (residential parking is exempt), and so may marginally increase retail prices, increase parking pricing, and reduce wages. Costs may be reduced if property owners are allowed to reduce their parking supply. To the degree that public transit improvements reduce the need to drive, any regressivity is further reduced.

- Travel Impacts - This tax may reduce parking supply and encourage property owners to price parking, which can reduce vehicle travel (Litman 2013; 
Wardman and Shire 2011). Travel impacts, therefore, depend on its magnitude, how it is applied, and the flexibility of local parking requirements.

- Strategic Development Objectives - This tax encourages reduced parking supply and therefore more compact development.

- Public Acceptance - Surveys and focus groups indicate relatively high support for parking taxes. Vancouver region experience indicates possible opposition from suburban businesses.

- Ease of Implementation - This tax would have relatively high implementation costs, since it requires adding a new field to property records, but once established, ongoing costs are likely to be modest.

- Legal Status - May require state or provincial legislation.

- Examples (IPIRG 2007; Litman 2012) - Melbourne, Perth, and Sydney all impose levies on city center non-residential parking spaces to encourage use of alternative modes and fund transport facilities and services. Small businesses are exempted. TransLink implemented a parking levy in 2006, but this was subsequently rejected by the provincial government.

\section{Expanded Parking Pricing}

This involves the expansion of where and when public parking is priced, such as metering currently unpriced on-street parking spaces in urban neighborhoods and charging for off-street parking at public facilities such as for government employees and at schools and parks. This is best implemented as part of a comprehensive parking management program that also includes better pricing systems, user information and enforcement practices.

Potential Revenue - Small to moderate. In most urban areas there are many unpriced publically-owned parking facilities that could be priced, although motorists will avoid using priced parking if possible. Currently only $1-2 \%$ of non-residential parking activity is priced, which probably averages $\$ 20-40$ annual per capita. If this can be tripled to $3-6 \%$ it would generate an additional $\$ 40-\$ 80$ annual per capita.

- Predictability and Stability - Relatively stable.

- Horizontal Equity - Like a fuel tax, this can be considered fair, since these valuable spaces are currently provided free to motorists, and to the degree 
that automobile travel imposes currently uncompensated external costs, and to the degree that motorists benefit from public transit improvements.

- Vertical Equity - Mixed. Lower-income households tend to own fewer vehicles and drive less than higher-income households, so overall impacts will vary depending on specific conditions, including lower-income vehicle ownership rates and the quality and price of transport and parking options.

- Travel Impacts - Parking pricing encourages people to reduce their vehicle ownership and use.

- Strategic Development Objectives - Mixed. If implemented as part of an integrated parking management program, efficient parking pricing can reduce the total number of parking spaces needed in an area and total vehicle travel, supporting more compact development. However, if parking is priced in a few major commercial areas it may favor suburban commercial areas, encouraging sprawl.

- Public Acceptance - Mixed. Motorists and businesses often oppose parking pricing, although the concept of user paid parking is gaining support as a way to reduce parking problems and generate local revenues.

- Ease of Implementation - Parking pricing tends to have relatively high implementation costs to install and operate pricing systems, plus additional transaction costs to motorists.

- Legal Status - Many jurisdictions already price public parking.

- Examples (Litman 2012; TCRP 2009) - Many communities price a portion of on-street and publically-owned off-street parking spaces.

\section{Development Cost Charges or Transportation Impact Fees}

These are fees on new development to help fund infrastructure costs (MRSC 2010). Transportation or traffic impact fee are sometimes dedicated to roadway improvements, so policy changes may be required to allow them to be spent on public transit improvements.

- Potential Revenue -Small to moderate. Since it applies only to new development, it depends on the amount of development occurring in the region.

- Predictability and Stability - Is highly variable depending on how it is applied and the amount of qualifying development that occurs. 
- Horizontal Equity - To the degree that new development increases demand for public transit or that developers benefit from high-quality transit service, it can be considered equitable.

- Vertical Equity - Uncertain. Although wealthier people tend to purchase more new housing, this fee will increase the costs of all new development and so will tend to increase rents and reduce housing affordability.

- Travel Impacts - If the charges discourage more compact, infill development, they may increase sprawled development and therefore automobile travel.

- Strategic Development Objectives - If the charges discourage more compact, infill development, they may increase sprawled development.

- Public Acceptance - Surveys and focus groups indicate relatively high support for development fees.

- Ease of Implementation - Implementation costs are minimal since development fees are already collected in most jurisdictions.

- Legal Status - Most municipalities governments and many region governments have a legal ability to collect such fees, although the use of such funds is often restricted to specific infrastructure, which may exclude public transit facilities and services.

- Examples (IPIRG 2007; TCRP 2009) - Many jurisdictions collect development or traffic/transportation impact fees.

\section{Land Value Capture}

This is a special property tax imposed in areas with high-quality public transit, intended to recover a portion of the increased land values provided by transit and to help finance the service improvements. It is sometimes called a transit benefit district tax (TRILLIUM Business Strategies 2009).

- Potential Revenue - Moderate to large over the long-run.

- Predictability and Stability - Difficult to predict, but stable once development occurs.

- Horizontal Equity - Considered horizontally equitable to the degree that 
high quality public transit provides an extra increase in land values and development revenues.

- Vertical Equity - Impacts depend on how the tax is structured and development conditions. It tends to capture value from developers and property owners, but some of the tax may be passed on to residents, and it can reduce housing affordability in transit-oriented developments (TODs), which is regressive.

- Travel Impacts - Depends on details. If such a tax discourages development around transit stations it could reduce transit ridership and TOD.

- Strategic Development Objectives - Mixed. May discourage some TOD, but it could encourage more concentrated development near transit stations.

- Public Acceptance - Surveys and focus groups indicate relatively high support for land value capture.

- Ease of Implementation - May require special analysis and legislation to determine the most appropriate tax structure.

- Legal Status - In some jurisdictions, state or provincial legislation and support would be required.

- Examples (TBoT 2010) - Land value capture in the form of transit benefit districts is used in some U.S. cities including Miami, Los Angeles, and Denver.

\section{Station Rents}

This involves collecting revenues from public-private developments on publicallyowned land in or near transit stations.

- Potential Revenue - Probably small. It depends on the transit agency's ability to obtain and develop land around transit stations and the demand for such building space.

- Predictability and Stability - Revenues are difficult to predict, but, once established, may be relatively stable.

- Horizontal Equity - Considered horizontally equitable to the degree that it captures the value of proximity to high quality public transit.

- Vertical Equity -Impacts depend on development conditions. It can be an opportunity for a community to raise additional revenue from businesses and higher income residents, but if rents are structured to maximize revenue 
it may reduce housing affordability in accessible locations (i.e., lower-priced housing in TODs), which is regressive.

- Travel Impacts - Uncertain. If this increases TOD, it may help reduce total vehicle travel.

- Strategic Development Objectives - Uncertain. It may increase or discourage TOD, depending on how development and rents are structured.

- Public Acceptance - Surveys and focus group responses indicate relatively high support for station rents.

- Ease of Implementation - Some station development may be relatively easy, but maximizing this revenue option may involve some effort and risks.

- Legal Status - Most transit agencies have the legal ability to develop stations, but may require state or provincial approval to condemn land for station development.

- Examples - Larger transit agencies with significant space in terminal and station facilities may enter into concession agreements (an income-generating strategy similar to leasing) with a variety of commercial and retail enterprises (TCRP 2009). For example, TransLink has established a Real Estate Division that is responsible for acquiring, managing and disposing of its properties in a manner that optimizes revenue, reduces capital costs, and supports strategic development goals such as station-area development (TransLink 2011).

\section{Station Air Rights}

This involves selling the rights to build over transit stations (Tompkins 2010).

- Potential Revenue - Depends on demand for such development. There are generally few sites where such development is feasible, so total potential revenues are probably modest.

- Predictability and Stability - Uncertain. Depends on demand for such development.

- Horizontal Equity - Considered horizontally equitable to the degree that it captures the value of proximity to high quality public transit.

- Vertical Equity -Impacts depend on specific conditions. It can raise revenue from businesses and higher income residents, but if structured to maximize 
revenue it may reduce housing affordability in accessible locations (i.e., lowerpriced housing in transit-oriented developments) which is regressive.

- Travel Impacts - Uncertain. If this increases TOD, it may help reduce total vehicle travel.

- Strategic Development Objectives - Uncertain. It may increase or discourage TOD, depending on how development and rents are structured.

- Public Acceptance - Surveys and focus groups indicate relatively high support for revenue-generating station area development.

- Ease of Implementation - Some station air rights development may be relatively easy, but maximizing this revenue option may involve some effort and risks.

- Legal Status - Most transit agencies probably have the legal right sell or rent station-area air rights.

- Examples (Tompkins 2010) - The Toronto Transit Commission has investigated options for selling air rights at the York Mills subway station, the Eglinton/ Yonge bus terminal, the Sheppard/Yonge station bus terminal, and land adjoining the Spadina station (Hall 2002).

\section{Advertising}

Most transit agencies collect revenues from transit vehicle, stop, and station advertising.

- Potential Revenue - Although expanding transit service and increasing transit ridership should allow more advertising, even doubling or tripling of revenue would provide relatively small additional revenue.

- Predictability and Stability - Relatively unstable.

- Horizontal Equity - No clear impact.

- Vertical Equity - No clear impact.

- Travel Impacts - No clear impact.

- Strategic Development Objectives - No clear impact.

- Public Acceptance - Surveys and focus groups indicate relatively high support for advertising. However, there may be public opposition to particular advertising methods or materials. 
- Ease of Implementation - Since most transit agencies already sell advertising, expansion is relatively easy.

- Legal Status - Already widely used.

- Examples (TCRP 2009) - Most public transit agencies generate revenue from advertising.

\section{Options Summary}

Table 3 summarizes the 18 funding options evaluated in this review.

Table 3. Potential Public Transport Funding Options

\begin{tabular}{|c|c|c|c|}
\hline Name & Description & Advantages & Disadvantages \\
\hline $\begin{array}{l}\text { Fare } \\
\text { increases }\end{array}$ & $\begin{array}{l}\text { Increase fares or change } \\
\text { fare structure to } \\
\text { increase revenues }\end{array}$ & $\begin{array}{l}\text { Widely applied; is a user } \\
\text { fee (considered equitable). }\end{array}$ & $\begin{array}{l}\text { Discourage transit use. } \\
\text { Is regressive. }\end{array}$ \\
\hline $\begin{array}{l}\text { Discounted } \\
\text { bulk passes }\end{array}$ & $\begin{array}{l}\text { Discount passes sold to } \\
\text { groups based on their } \\
\text { ridership }\end{array}$ & $\begin{array}{l}\text { Increases revenue and } \\
\text { transit ridership }\end{array}$ & $\begin{array}{l}\text { Increases transit service } \\
\text { costs and so may pro- } \\
\text { vide little net revenue }\end{array}$ \\
\hline $\begin{array}{l}\text { Property } \\
\text { taxes }\end{array}$ & $\begin{array}{l}\text { Increase local property } \\
\text { taxes }\end{array}$ & $\begin{array}{l}\text { Widely applied; distributes } \\
\text { burden widely }\end{array}$ & $\begin{array}{l}\text { Supports no other } \\
\text { objectives; considered } \\
\text { regressive. }\end{array}$ \\
\hline Sales taxes & Special local sales tax & Distributes burden widely & $\begin{array}{l}\text { Supports no other } \\
\text { objectives; regressive }\end{array}$ \\
\hline Fuel taxes & $\begin{array}{l}\text { Additional fuel tax in } \\
\text { region }\end{array}$ & $\begin{array}{l}\text { Widely applied; reduces } \\
\text { vehicle traffic and fuel use }\end{array}$ & Considered regressive \\
\hline Vehicle fees & $\begin{array}{l}\text { Additional fee for } \\
\text { vehicles registered in } \\
\text { region }\end{array}$ & $\begin{array}{l}\text { Applied in some jurisdic- } \\
\text { tions; charges motorists } \\
\text { for costs }\end{array}$ & $\begin{array}{l}\text { Does not affect vehicle } \\
\text { use }\end{array}$ \\
\hline Utility levy & $\begin{array}{l}\text { Levy to all utility } \\
\text { accounts in region }\end{array}$ & $\begin{array}{l}\text { Easy to apply; distributes } \\
\text { burden widely }\end{array}$ & $\begin{array}{l}\text { Small, regressive, and } \\
\text { supports no other } \\
\text { objectives }\end{array}$ \\
\hline $\begin{array}{l}\text { Employee } \\
\text { levy }\end{array}$ & $\begin{array}{l}\text { Levy on each employee } \\
\text { within a designated } \\
\text { area or jurisdiction }\end{array}$ & Charges for commuters & $\begin{array}{l}\text { Requires collection } \\
\text { system; may encourage } \\
\text { sprawl if only in city } \\
\text { centers }\end{array}$ \\
\hline
\end{tabular}


Table 3. Potential Public Transport Funding Options (cont'd.)

\begin{tabular}{|c|c|c|c|}
\hline Name & Description & Advantages & Disadvantages \\
\hline Road tolls & $\begin{array}{l}\text { Tolls on some roads or } \\
\text { bridges }\end{array}$ & Reduces traffic congestion & $\begin{array}{l}\text { Costly to implement; } \\
\text { can encourage sprawl } \\
\text { if only applied in city } \\
\text { centers }\end{array}$ \\
\hline $\begin{array}{l}\text { Vehicle-Km } \\
\operatorname{tax}\end{array}$ & $\begin{array}{l}\text { Distance-based fee on } \\
\text { vehicles registered in } \\
\text { region }\end{array}$ & Reduces vehicle traffic & Costly to implement \\
\hline Parking taxes & $\begin{array}{l}\text { Special tax on commer- } \\
\text { cial parking transac- } \\
\text { tions }\end{array}$ & Applied in many cities. & $\begin{array}{l}\text { Discourages parking } \\
\text { pricing and downtown } \\
\text { development }\end{array}$ \\
\hline Parking levy & $\begin{array}{l}\text { Special property tax } \\
\text { on parking spaces } \\
\text { throughout region }\end{array}$ & $\begin{array}{l}\text { Large potential; distributes } \\
\text { burden widely, encourages } \\
\text { compact development }\end{array}$ & $\begin{array}{l}\text { Costly to implement; } \\
\text { opposed by suburban } \\
\text { property owners }\end{array}$ \\
\hline $\begin{array}{l}\text { Expanded } \\
\text { parking } \\
\text { pricing }\end{array}$ & $\begin{array}{l}\text { Increase when and } \\
\text { where public parking } \\
\text { facilities (such as on- } \\
\text { street parking spaces) } \\
\text { are priced }\end{array}$ & $\begin{array}{l}\text { Moderate to large poten- } \\
\text { tial; distributes burden } \\
\text { widely, reduces driving. }\end{array}$ & $\begin{array}{l}\text { Costly to implement; } \\
\text { May discourage down- } \\
\text { town business activity. }\end{array}$ \\
\hline $\begin{array}{l}\text { Development } \\
\text { or transport } \\
\text { impact fees }\end{array}$ & $\begin{array}{l}\text { Fee on new develop- } \\
\text { ment to help finance } \\
\text { infrastructure, includ- } \\
\text { ing transit improve- } \\
\text { ments }\end{array}$ & Charges beneficiaries & Limited potential \\
\hline $\begin{array}{l}\text { Land value } \\
\text { capture }\end{array}$ & $\begin{array}{l}\text { Special taxes on prop- } \\
\text { erty that benefit from } \\
\text { the transit service }\end{array}$ & $\begin{array}{l}\text { Large potential; charges } \\
\text { beneficiaries. }\end{array}$ & $\begin{array}{l}\text { May be costly to imple- } \\
\text { ment; may discourage } \\
\text { TOD }\end{array}$ \\
\hline Station rents & $\begin{array}{l}\text { Collect revenues from } \\
\text { public-private develop- } \\
\text { ment at stations }\end{array}$ & Charges beneficiaries & Limited potential \\
\hline $\begin{array}{l}\text { Station air } \\
\text { rights }\end{array}$ & $\begin{array}{l}\text { Sell rights to build over } \\
\text { transit stations }\end{array}$ & Charges beneficiaries & Limited potential \\
\hline Advertising & $\begin{array}{l}\text { Additional advertising } \\
\text { on vehicles and stations }\end{array}$ & Already used & $\begin{array}{l}\text { Limited potential; } \\
\text { sometimes unattractive }\end{array}$ \\
\hline
\end{tabular}




\section{Conclusions}

Public transit service improvements are an important component of many regions' transportation system improvement plans. High-quality public transit services can provide various economic, social, and environmental benefits, including direct user benefits and various indirect and external benefits.

Implementing transit improvements often requires additional funding. Although federal, state, or provincial funding may be available, new local funding is generally needed. Based on a detailed review of existing literature, this study identified 18 funding options, including some that are widely used and others considered innovative and used only in a few jurisdictions.

These potential funding options were evaluated against eight criteria. Evaluation results can vary depending on perspective and assumptions. Equity analysis is particularly subjective depending on how equity is defined and impacts measured. From some perspectives, it is most equitable to generate transit funding from a narrowlydefined group of beneficiaries, such as users of a new transit service, employers who generate commute trips, or owners of transit station area properties. However, high-quality public transit tends to provide multiple, dispersed benefits, including external benefits to people who do not currently use the service but benefit from reduced traffic and parking congestion, improved safety, reduced need to chauffeur non-drivers, energy conservation and emission reductions, and increased regional economic development. Public transit improvements tend to provide a broader scope of benefits than highway expansion, so a wider range of funding options can be justified for the sake of horizontal equity (i.e., beneficiaries pay).

Widely-used public transit funding sources include fares, property taxes, sales taxes, fuel taxes, advertising, and station rents. There is potential for increasing revenues from these options, although fare increases contradict other planning objectives. Fuel tax increases and expanded parking pricing (more frequently charging motorists for using public parking facilities, particularly on-street parking in urban neighborhoods) are particularly appropriate because they also encourage fuel conservation and more efficient transport, in addition to raising revenues. However, these taxes and fees are considered burdensome and regressive (their actual regressivity depends on the quality of transport options available, and so is reduced by public transit service improvements) and so should be implemented gradually.

The options that seem most acceptable to the public (development and transportation impact fees, station rents, advertising) tend to generate modest revenue. 
Economists are particularly enthusiastic about congestion pricing, but it tends to be costly and politically difficult to implement, and total revenues are often modest since tolls are only collected on a small portion of total vehicle travel.

Three new revenue options with significant potential deserve more consideration: parking levies (special property taxes on non-residential parking spaces throughout the region), vehicle levies (an additional fee on vehicles registered in the region) and employee levies (a levy on each employee, often only collected from larger employers). These could generate relatively large amounts of revenue, distribute costs broadly, and have a logical connection to transit improvements (high-quality transit benefits motorists, businesses, and employees). A parking levy applied to all non-residential parking spaces in a region would disperse the financial burden and support strategic planning objectives by encouraging more compact development and more efficient parking pricing. These three options have moderate implementation costs, more than increasing existing transit funding options, but less than road tolls or vehicle-kilometer fees.

Where feasible, development and transportation impact fees, station rents, and air rights can be used to generate funds, but their revenues will vary depending on future demand for transit-area development, and so are difficult to predict and are likely to be modest in most cases.

Land value capture taxes and levies should also be considered. They should be structured to avoid discouraging TOD (they should not be too high or geographically concentrated), and it may be best to defer their implementation for a few years until station-area demand rises sufficiently. It is particularly appropriate to create local area benefit districts around transit stations where modest special levies and parking pricing revenues are used primarily to finance local improvements such as station amenities, streetscaping and special cleaning, and security services, rather than financing system-wide transit services.

This research discovered no new funding options that are particularly cost-effective and easy-to-implement. Each option has disadvantages and constraints. As a result, this study's overall conclusion is that a variety of funding options should be used to help finance the local share of public transit improvements to ensure stability (so total revenues are less vulnerable to fluctuations in a single economic sector or legal instrument) and distribute costs broadly. Public transit improvements often provide widely dispersed benefits that can justify widely dispersed funding sources. Even people who do not currently use public transit benefit from reduced conges- 
tion, increased public safety and health, improved mobility option for non-drivers, regional economic development, and improved environmental quality.

Additional research is recommended to better understand the impacts of these options. Revenue options that are implemented should be structured to maximize benefits and minimize problems. Taxes and levies should be designed to support other regional planning objectives, including increased transit ridership, reduced automobile traffic, economic development, energy conservation, compact development, and greenspace preservation and affordability.

\section{Acknowledgments}

This paper is based on research sponsored by the Victoria Regional Transit Commission (VRTC) and the Capital Regional District (CRD). Thanks to my research partners Jan Pezarro and Mark Pezarro and fellow Task Force members Robert Lapham, Jonathan Norgaard, Erinn Pinkerton, and Marg Misek-Evans.

\section{References}

APTA. 2012. Primer on transit funding: FY 2004 through FY 2012. American Public Transportation Association, www.apta.com/gap/policyresearch/Documents/ Primer_SAFETEA_LU_Funding.pdf.

Banister, David, and Mark Thurstain-Goodwin. 2011. Quantification of the nontransport benefits resulting from rail investment. Journal of Transport Geography 19(2), March, 212-223; earlier version at www.tsu.ox.ac.uk/pubs/1029banister.pdf.

BC Transit and CRD. 2012. Victoria Regional Rapid Transit local funding options website, www.Irtlocalfunding.ca, BC Transit and Capital Regional District.

Baxandall, Phineas. 2007. Finding solutions to fund transit combining accountability and new resources for world-class public transportation, U.S. PIRG, www. uspirg.org.

Boulder. 2013. Neighborhood Eco (NECO) Pass. City of Boulder, www.bouldercolorado.gov/index.php?option $=$ com_content $\&$ task=view\&id $=8835 \& / t e m i d=30$ 02. 
Brown, Jeffrey, Daniel Baldwin Hess, and Donald Shoup. 2003. Fare-free public transit at universities: An evaluation. Journal of Planning Education and Research 23, www.sppsr.ucla.edu//dup/people/faculty/shoup/fare-free.pdf), 69-82.

Buehler, Ralph, and John Pucher. 2010. Making public transport financially sustainable. Transport Policy 18, http://policy.rutgers.edu/faculty/pucher/Sustainable. pdf.

CTOD. 2011. Transit and regional economic development. Center for Transit Oriented Development, http://reconnectingamerica.org/assets/Uploads/TransitandRegionalED2011.pdf.

Earthvoice Strategies. 2012. Victoria Regional Rapid Transit project: Survey of public transit capital funding strategies in Canadian peer communities. CRD Local Funding Options, www.crd.bc.ca/reports/transportationselect_/2012_/06j une27_/ppsrp201216appendixc/ppsrp201216appendixc.pdf.

Hall, Joseph. 2002. TTC explores selling station "air rights." Toronto Star, http:// transit.toronto.on.ca/archives/data/200203200100.shtml.

Huang, Edward, Henry Lee, Grant Lovellette, and Jose Gomez-lbañez. 2010. Transportation revenue options: Infrastructure, emissions, and congestion. Belfer Center, Harvard Kennedy School, http://belfercenter.ksg.harvard.edu/ files/Transportation\%20Revenue\%20Options\%20Workshop\%20Report\%20 2010\%20for\%20web.pdf.

IPIRG. 2007. Finding solutions to fund transit: Combining accountability and new resources for world-class public transportation. Illinois Public Interest Research Group, http://financecommission.dot.gov/Documents/IL_transit_report_ June\%202007.pdf.

Litman, Todd. 2002. Evaluating transportation equity. World Transport Policy \& Practice 8(2), Summer, 50-65

Litman, Todd. 2004. Transit price elasticities and cross-elasticities. Journal of Public Transportation 7(2), 37-58.

Litman, Todd. 2009. Transport cost and benefit analysis. Victoria transport Policy Institute, www.vtpi.org/tca.

Litman, Todd. 2010. Raise my taxes, please! Evaluating household savings from high quality public transit service. VTPI, www.vtpi.org/raisetaxes.pdf. 
Litman, Todd. 2011. Evaluating public transit benefits and costs. Victoria Transport Policy Institute, www.vtpi.org/tranben.pdf.

Litman, Todd. 2012. Parking pricing implementation guidelines: How more efficient pricing can help solve parking problems, increase revenue, and achieve other planning objectives. Victoria Transport Policy Institute, www.vtpi.org/ parkpricing.pdf.

Litman, Todd. 2013. Transport elasticities: Impacts on travel behaviour: understanding transport demand to support sustainable travel behavior. Technical Document \#11, Sustainable Urban Transport Project and GIZ, www.sutp.org/ index.php/en-dn-tp. Also see, Understanding transport demands and elasticities: How prices and other factors affect travel behavior, www.vtpi.org/elasticities.pdf.

McCollom, Brian E., and Richard Pratt. 2004. Transit pricing and fares. Chapter 12, TCRP Report 95, Transit Cooperative Research Program, www.trb.org/publications/tcrp/tcrp_rpt_95c12.pdf.

METRO. 2011. Measure $r$ works for LA. www.metro.net/projects/measurer.

MRSC. 2010. Transportation impact fees. Municipal Research and Service Center of Washington, www.mrsc.org/subjects/planning/transimpactfees.aspx.

Quay Communications, Inc. 2012. Victoria Regional Rapid Transit: Local funding options focus group report. CRD Local Funding Options Capital Regional District, www.crd.bc.ca/reports/transportationselect_/2012_/06june27_/ ppsrp201216appendixe/ppsrp201216appendixe.pdf.

Sakamoto, Ko, Stefan Belka, and Gerhard P. Metschies. 2010. Financing sustainable urban transport. GTZ Sourcebook Module, Sustainable Urban Transport Project Asia and the German Technical Cooperation, www2.gtz.de/urbanet/ library/detail1.asp?number $=8114$.

Smith, Jeffery J., and Thomas A. Gihring. 2003. Financing transit systems through value capture: An annotated bibliography. Geonomy Society, www.vtpi.org/ smith.pdf.

TBoT. 2010. The move ahead: Funding "The Big Move." Toronto Board of Trade, www. bot.com/AM/Template.cfm?Section=Growing_the_Economy\&Template=/ $\mathrm{CM} /$ ContentDisplay. cfm\&ContentID $=4702$. 
TCRP. 1998. Funding strategies for public transportation. Report 31, Transit Cooperative Research Program (TCRP), http://onlinepubs.trb.org/onlinepubs/tcrp/ tcrp_rpt_31-1-a.pdf.

TCRP. 2009. Local and regional funding mechanisms for public transportation. Report 129, Transit Cooperative Research Program (TCRP), http://onlinepubs. trb.org/onlinepubs/tcrp/tcrp_rpt_129.pdf.

Tompkins, James. 2010. "Air rights" in Ottawa: Maximizing the value of public transit infrastructure. Journal of Public Transit in Ottawa, http://transitottawa. netfirms.com/transitottawa.ca/JPTO_Vol1_W2010.pdf.

TransLink. 2011. Doing business with translink: Real estate. TransLink, www.translink.ca/en/About-Us/Doing-Business-with-TransLink/Real-Estate.aspx.

Trillium Business Strategies Inc. 2009. Land value capture as a tool to finance public transit projects in Canada. Surface Policy Directorate Transport Canada, www. tc.gc.ca/eng/policy/report-acg-land-value-menu-1726.htm.

UTCM. 2010. A guide to transportation funding options; Transit funding - Summary of funding strategies. University Transportation Center for Mobility, Texas Transportation Institute, http://utcm.tamu.edu/tfo/transit/summary.stm.

Wardman, Mark, and Jeremy Shires. 2011. Price elasticities of travel demand in Great Britain: A meta-analysis. Paper 11-3544, Transportation Research Board Annual Meeting, http://trid.trb.org/view.aspx?id=1093095.

\section{About the Author}

TODD LiTMAN (litman@vtpi.org) is founder and executive director of the Victoria Transport Policy Institute, an independent research organization dedicated to developing innovative solutions to transport problems. His work helps expand the range of impacts and options considered in transportation decision-making, improve evaluation methods, and make specialized technical concepts accessible to a larger audience. His research is used worldwide in transport planning and policy analysis. Mr. Litman has worked on numerous studies that evaluate transportation costs, benefits, and innovations. He is active in several professional organizations including the Institute of Transportation Engineers and the Transportation Research Board. 